\title{
The Determinants of Interest Rate Spreads in South Africa: A Cointegration Approach
}

\author{
${ }^{1}$ Ferdinand Niyimbanira*, ${ }^{2}$ Rachel Nishimwe-Niyimbanira, ${ }^{2}$ Sanderson Sabie Kuyeli, ${ }^{1}$ Koleka Rangaza \\ ${ }^{1}$ Vaal University of Technology, South Africa \\ ${ }^{2}$ North West University, South Africa \\ *ferdinandn@vut.ac.za
}

\begin{abstract}
This study empirically identifies the determinants of interest rate spreads (IRS) in South Africa over the period 1990 to 2012. The study uses the Johansen Cointegration Approach and Vector ErrorCorrection techniques to identify the variables in explaining the interest rate spreads in South Africa. It considers the inflation rate, reserve requirements, Treasury bill, discount rate, money supply (M2) and gross domestic product per capita variables as they explain the movement of interest rate spreads. A significant short-run relationship between IRS and its explanatory variables was observed. These macroeconomic variables are significant in explaining the behavior of the South African IRS in the longrun. This paper has focused on illuminating on how the interest rate spreads are impacted by both exogenous and endogenous variables. If controlled, these variables are most likely to have the largest effects on reducing such spreads. In addition, it suggests that the reduction in the reserve requirements prescribed by the South African Reserve Bank would help to reduce the interest rate spreads. Based on the results of the study, policy implications and suggestion for future research are made.
\end{abstract}

\section{Keywords: Interest rate spread, cointegration, Vector error correction, South Africa}

\section{Introduction}

Interest rate spreads represent an important element for financial stability. They form a substantial part of bank growth. Even though there has been an increase in interest rate spreads, little research has been done on the determinants of interest rate spreads based on South African data. Hainz, Horvath \& Hlavacek (2014) noted that most previous studies conducted on interest rate spreads used yearly frequency, implying a need to fill this gap by using quarterly data. On top of their prominence in the bank performance, interest rate spreads tend to have a number of important implications for any meaningful development of an economy. High interest rate spreads are likely to discourage potential savers and in the process thus limit the stable availability of funds to potential investors (Akinlo \& Owoyemi, 2012). Structural, informational and institutional inefficiencies characterises financial systems in many of the developing and underdeveloped countries, and consequentially leading to high margins between commercial banks' lending and borrowing rates (Afzal \& Mirza, 2010:3). In South Africa, like many of the developing countries, high interest rate spreads are still an issue of concern despite the liberalization of the financial sector. Elevated and volatile lending rates are cited as main causes of higher interest rate spreads, which also leads to higher costs of capital for borrowers. Higher interest rate spreads tend to favour and promote only those short-term high-risk ventures, thereby reducing the potential for longterm investment opportunities. Banda (2010) also reports that higher banking spreads can have a negative impact for businesses with less financial flexibility and in particular small and medium enterprises. Persistent high spreads are therefore a critical indicator of the poor performing financial system and among other things pointing to the inefficiencies in the banking regulation framework, and can consequently slow down or hinder economic growth.

Therefore, the main objective of this paper is firstly to investigate the determinants of interest rate spreads in South Africa; secondary to analyse the relationship between macroeconomic variables and IRS. This paper also seeks to ascertain how macroeconomic and banking sector indicator affects interest rate spread in South Africa and offer few suggestions for improving the IRS in South Africa if needed. Mettle (2013) defines the interest rate spread in terms of the market microstructure characteristics of the banking sector and the policy environment. However, Ho \& Saunders (1981) evoke at it in terms of the difference between the pure and the actual spread. They observe that pure spread is a microstructure phenomenon, which is influenced by the level of degree of bank risk management, the size of bank transactions, interest rate elasticity and interest rate variability. Considering the risk management by the bank, Zarruk (1989) found that there is a difference in the levels of spreads between banks that are risk averse and those that are risk neutral. The findings were that banks that are risk-averse tend to operate 
with a minimal spread unlike the risk-neutral banks. However, Paroush (1994) on the other hand suggests that the nature of banks affects the interest rate as the risk-averse banks are likely to raise their optimal interest rate and eventually leading to the reduction of credit supplied. On the other hand, the macroeconomic activities such as monetary and fiscal policy undertakings further influence both the actual and pure interest rate spread. Hanson and Rocha (1986) also emphasize the role direct taxes, reserve requirements, cost of transactions and forced investment play in shaping the interest rate spread. However, Banda (2010) cites exchange rate instability and high and variable inflation as the underlining constraints to corporations' and households' ability in executing their loan obligations, where especially when it compromises their balance sheets. This assertion is also supported by the empirical studies for developing countries by Brock \& Rojas-Suarez (2000) and Demirguc-Kunt \& Huizinga (1999).which confirms a positive relationship between inflation and interest rate spreads.

It is not surprising though that South African financial reform emphasizes the need to abolish interest rate and credit ceilings in favour of a competitive environment with less government control and ownership. This in a way however, is not by implication suggesting non-existence of interest rate spreads to achieve the competitive environment, as suggested by Ho \& Saunders (1981), the non-competitive markets is more conducive to higher spreads. Note that the size of the spread is much higher in a noncompetitive market. This then calls for strengthening the regulatory and legal framework to promote and hedge stability of the market. Caprio (1996) warns of weak legal systems in which there is no prompt enforcement of contracts and characterised with ill defined property rights. This can thus lead to increased credit riskiness and with banks having no incentives to charge lower rates. Cho (1988), in addition, observes some shortfalls in the liberalization theory which overlooks the endogenous constraints for efficient allocation of resources by the banking sector. This is mainly where there is a missing link of a well-functioning equities market, leading to inefficient allocation of capital even where there is financial liberalization. Fry (1995) explains that financial institutions have a tendency of absorbing too much risk in an environment rocked with no direct financial markets and an equity and bonds market. This is mainly due to the fact that business enterprises over depend on debt finance. Indeed, the interest rate spread fluctuations entails the substitution between debt and equity financing. As the equity market grows and providing competitive returns, banks increase their deposit rates as way of attracting for funds from the public (Demirguc-Kunt \& Huizinga, 1999).

The expanded market plays also a pivotal role towards the banking sector as it tends to reduce the risk absorbed by the banks. This in turn enables the banks to provide reduced interest rates margins as banks offers competitive lower lending rates. But as Fry (1995) remarks that there is always need for competition in the direct financial market even where there is an oligopolistic banking system. Empirical results show that imperfections in the market enhance the widening of interest rate spread. Ho \& Saunders (1981), in examining the relationship between market power and bank size, found a significant difference in spread between large and small banks. The results revealed that smaller banks had higher spreads than the larger banks. Barajas et al. (1996) also show a significant low played by loan market power in influencing the interest rate spread; and this was further observed by Elkayam (1996), in a competitive banking system. The interest rate spread is solely derived from the central bank variables (including the discount window loans, reserve requirement and interest on liquid assets on deposit with the central bank), while under a monopolistic (or oligopolistic) structure the interest rate spread is in addition affected by elasticity exerted by the demand for credit and deposits. He also found credit markets have more market power than the deposit market. In taking into account the monetary policy, Elkayam (1996) found that spread is more negatively affected by an increase in money supply, especially under elastic demand, in monopolistic as compared to a competitive market. The spread hence provides vital information as far as efficiency of financial intermediation, matters of profitability, as well as policy impact are concerned. An analysis of bank interest rate spreads is therefore central not only to the understanding of the financial intermediation process but also dynamics of the macroeconomic environment in which banks operate.

\section{Methodology}

In the light of what discussed above, to achieve the empirical findings the following are the mathematical (1) and econometric (2) models formulated to determine the interest rate spreads and its explanatory variables in South Africa.

$I R S=f(G D P, I N F, D I S R A T E, R R, T B I L L, M 2)$

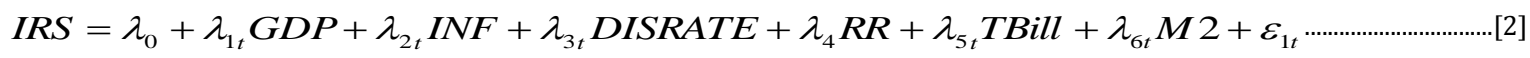


Where IRS $=$ Interest rate spreads, GDP $=$ Log of GDP $/$ capita, INF $=$ Inflation rate, DISRATE $=$ Discount rate, $\mathrm{RR}=$ Reserve requirements, $\mathrm{TBill}=$ Treasury Bill and M2 $=\log$ of Money supply.

The secondary data used in the empirical examination covers quarterly data for the period from the third quarter of 1990 to the fourth quarter of 2012; which give a sample size of 90. It is believed that the results from a sample size of time series equal to or greater than 30 make more sense than the ones from a small sample size (<30) (Keller \& Warrack, 2003) and (Mann, 2004). Beside Inflation which was collected from Statistics South Africa, other variables are collected from South African Reserve Bank. The coefficients of all variables are expected to be positive.

To examine the nature of any long-run relationship between interest rate spreads and its determinants as suggested in the model, firstly there is need to investigate as to whether the series are cointegrated, in other words determining the existence of stationarity in the deviations from any long-run equilibrium relationship that exists between them (Aqeel \& Nishat, 2005:5). Several researchers such as Engle \& Granger (1987), Johansen (1988) and Engle \& Yoo (1987) developed the theory of cointegration in the 1980s and 90s. Similarly, Robinson \& Marinucci (2003: 334) ascertains that cointegration analysis has been developed as a major theme of time series econometrics and generated much interest in 1990s when it led to its considerable methodological and theoretical developments. Therefore the cointegration method is considered as a useful econometric tool (Johansen \& Juselius, 1990:192). According to Harris (1995:22), "if a series must be differenced $d$ times before it becomes stationary, then it contains $d$ unit roots and is said to be integrated of order $d$, denoted $I(d)$." This means that inference is worthless only when there is a long-run equilibrium relationship between variables. In other words only when variables are cointegrated (Brook, 2008). Therefore, the presence of cointegration between dependent and independent variables ensures that an ordinary least square (OLS) regression in levels yields consistent parameter estimates (Engle \& Granger, 1987). In addition, according to Aqeel \& Nishat (2005: 5) "discovering that variables are cointegrated, allows for the use of error correction models which allow for separation out of long-run and short-run impact."

According to Muzindutsi \& Sekhampu (2013)'s study, the dependent variable (IRS in this case) may be related to its own lag values and to those of independent variables; a Vector Autoregressive (VAR) model is used in modelling the multivariate relationships between IRS and its macroeconomic determinants. The VAR is a form of starting point for different analysis such as co-integration analysis, causality test, stability test, and impulse response (Chan, 2010; Maddala, 2001). The VAR model for this paper is as follows:

$$
\begin{aligned}
& I R S_{t}=\alpha_{1}+\sum_{J=1}^{K} \beta_{1 j} I R S_{t-j}+\sum_{j=1}^{k} \lambda_{1 j} G D P_{t-j}+\sum_{j=1}^{k} \gamma_{1 j} I N F_{t-j}+\sum_{j=1}^{k} \psi_{1 j} D I S R A T E_{t-j}+\sum_{j=1}^{k} \theta_{1 j} R R_{t-j}+ \\
& \sum_{j=1}^{k} S_{1 j} T B i l l_{t-j}+\sum_{j=1}^{k} \delta_{1 j} L M 2_{t-j}+\varepsilon_{1_{t}} \\
& G D P_{t}=\alpha_{2}+\sum_{J=1}^{K} \beta_{2 j} I R S_{t-j}+\sum_{j=1}^{k} \lambda_{2 j} G D P_{t-j}+\sum_{j=1}^{k} \gamma_{2 j} I N F_{t-j}+\sum_{j=1}^{k} \psi_{2 j} D I S R A T E_{t-j}+\sum_{j=1}^{k} \theta_{2 j} R R_{t-j}+ \\
& \sum_{j=1}^{k} \varsigma_{2 j} \text { TBill }_{t-j}+\sum_{j=1}^{k} \delta_{2 j} L M 2_{t-j}+\varepsilon_{2} \\
& I N F_{t}=\alpha_{3}+\sum_{J=1}^{K} \beta_{3 j} I R S_{t-j}+\sum_{j=1}^{k} \lambda_{3 j} G D P_{t-j}+\sum_{j=1}^{k} \gamma_{3 j} I N F_{t-j}+\sum_{j=1}^{k} \psi_{3 j} D I S R A T E_{t-j}+\sum_{j=1}^{k} \theta_{3 j} R R_{t-j}+ \\
& \sum_{j=1}^{k} \varsigma_{3 j} \text { TBill }_{t-j}+\sum_{j=1}^{k} \delta_{3 j} L M 2_{t-j}+\varepsilon_{3 t} \\
& \operatorname{DISRATE}_{t}=\alpha_{4}+\sum_{J=1}^{K} \beta_{4 j} I R S_{t-j}+\sum_{j=1}^{k} \lambda_{4 j} G D P_{t-j}+\sum_{j=1}^{k} \gamma_{4 j} I N F_{t-j}+\sum_{j=1}^{k} \psi_{4 j} \operatorname{DISRATE}_{t-j}+\sum_{j=1}^{k} \theta_{4 j} R R_{t-j}+
\end{aligned}
$$

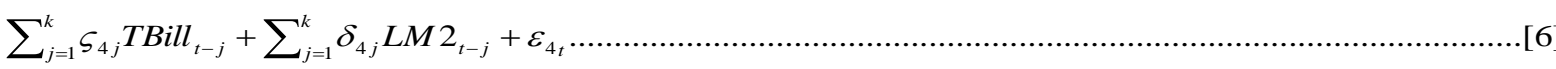

$$
\begin{aligned}
& R R_{t}=\alpha_{5}+\sum_{J=1}^{K} \beta_{5 j} I R S_{t-j}+\sum_{j=1}^{k} \lambda_{5 j} G D P_{t-j}+\sum_{j=1}^{k} \gamma_{5 j} I N F_{t-j}+\sum_{j=1}^{k} \psi_{5 j} \operatorname{DISRATE}_{t-j}+\sum_{j=1}^{k} \theta_{5 j} R R_{t-j}+ \\
& \sum_{j=1}^{k} \varsigma_{51 j} T_{B i l l}+\sum_{t-j}^{k} \delta_{5 j} L M 2_{t-j}+\varepsilon_{5} \\
& \text { TBill }_{t}=\alpha_{6}+\sum_{J=1}^{K} \beta_{6 j} I R S_{t-j}+\sum_{j=1}^{k} \lambda_{6 j} G D P_{t-j}+\sum_{j=1}^{k} \gamma_{6 j} I N F_{t-j}+\sum_{j=1}^{k} \psi_{6 j} D_{I S R A T E} E_{t-j}+\sum_{j=1}^{k} \theta_{6 j} R R_{t-j}+ \\
& \sum_{j=1}^{k} \varsigma_{6 j} T_{B i l l}+\sum_{j=1}^{k} \delta_{6 j} L M 2_{t-j}+\varepsilon_{6 t} \\
& L M 2_{t}=\alpha_{7}+\sum_{J=1}^{K} \beta_{7 j} I R S_{t-j}+\sum_{j=1}^{k} \lambda_{7 j} G D P_{t-j}+\sum_{j=1}^{k} \gamma_{7 j} I N F_{t-j}+\sum_{j=1}^{k} \psi_{7 j} D I S R A T E_{t-j}+\sum_{j=1}^{k} \theta_{7 j} R R_{t-j}+ \\
& \sum_{j=1}^{k} \varsigma_{7 j} \text { TBill }_{t-j}+\sum_{j=1}^{k} \delta_{7 J} L M 2_{t-j}+\varepsilon_{7 t}
\end{aligned}
$$


Where $\alpha$ is the intercept; $\beta, \lambda, \gamma, \psi, \theta, \varsigma$ and $\delta$ are the coefficients; $\mathrm{k}$ is number of lags and $\varepsilon^{\prime}$ s are the stochastic error terms (known as shocks in a VAR model). Before estimating the above equations, the Augmented Dickey Fuller (ADF) test was used to test for the unit root in the variables. If the variables have a unit root, a co-integration test is generally undertaken to establish whether non-stationary variables move together over time and have a linear combination (Brooks, 2008). This study used the Johansen's multivariate co-integrating VAR approach to identify whether there is a long run relationship between the variables. If the co-integration test indicates that variables are not co-integrated, then the VAR model will be the one to be used. Alternatively, the following VECM will be estimated if variables are co-integrated.

$$
\begin{aligned}
& \Delta I R S_{t}=\alpha_{1}+\sum_{J=1}^{K} \beta_{1 j} \Delta I R S_{t-j}+\sum_{j=1}^{k} \lambda_{1 j} \Delta G D P_{t-j}+\sum_{j=1}^{k} \gamma_{1 j} \Delta I N F_{t-j}+\sum_{j=1}^{k} \psi_{1 j} \Delta D I S R A T E_{t-j}+\sum_{j=1}^{k} \theta_{1 j} \Delta R R_{t-j}+ \\
& \sum_{j=1}^{k} \varsigma_{1 j} \Delta \text { BBill }_{t-j}+\sum_{j=1}^{k} \delta_{1 j} \Delta L M 2_{t-j}+\Omega_{1} u_{2 t-1}+\varepsilon_{1 t} \\
& \Delta G D P_{t}=\alpha_{2}+\sum_{J=1}^{K} \beta_{2 j} \Delta I R S_{t-j}+\sum_{j=1}^{k} \lambda_{2 j} \Delta G D P_{t-j}+\sum_{j=1}^{k} \gamma_{2 j} \Delta I N F_{t-j}+\sum_{j=1}^{k} \psi_{2 j} \Delta D I S R A T E_{t-j}+\sum_{j=1}^{k} \theta_{2 j} \Delta R R_{t-j}+ \\
& \sum_{j=1}^{k} \varsigma_{2 j} \Delta T B i l l_{t-j}+\sum_{j=1}^{k} \delta_{2 j} \Delta L M 2_{t-j}+\Omega_{2} u_{2 t-1}+\varepsilon_{2 t} \\
& \Delta I N F_{t}=\alpha_{3}+\sum_{J=1}^{K} \beta_{3 j} \Delta I R S_{t-j}+\sum_{j=1}^{k} \lambda_{3 j} \Delta G D P_{t-j}+\sum_{j=1}^{k} \gamma_{3 j} \Delta I N F_{t-j}+\sum_{j=1}^{k} \psi_{3 j} \Delta D I S R A T E_{t-j}+\sum_{j=1}^{k} \theta_{3 j} \Delta R R_{t-j}+ \\
& \sum_{j=1}^{k} \varsigma_{3 j} \Delta T B i l l_{t-j}+\sum_{j=1}^{k} \delta_{3 j} \Delta L M 2_{t-j}+\Omega_{3} u_{3 t-1}+\varepsilon_{3 t} \\
& \Delta D I S R A T E_{t}=\alpha_{4}+\sum_{J=1}^{K} \beta_{4 j} \Delta I R S_{t-j}+\sum_{j=1}^{k} \lambda_{4 j} \Delta G D P_{t-j}+\sum_{j=1}^{k} \gamma_{4 j} \Delta I N F_{t-j}+\sum_{j=1}^{k} \psi_{4 j} \Delta D I S R A T E_{t-j}+ \\
& \sum_{j=1}^{k} \theta_{4 j} \Delta R R_{t-j}+\sum_{j=1}^{k} \varsigma_{4 j} \Delta T \text { Bill } l_{t-j}+\sum_{j=1}^{k} \delta_{4 j} \Delta L M 2_{t-j}+\Omega_{4} u_{4 t-1}+\varepsilon_{4 t} \\
& \Delta R R_{t}=\alpha_{5}+\sum_{J=1}^{K} \beta_{5 j} \Delta I R S_{t-j}+\sum_{j=1}^{k} \lambda_{5 j} \Delta G D P_{t-j}+\sum_{j=1}^{k} \gamma_{5 j} \Delta I N F_{t-j}+\sum_{j=1}^{k} \psi_{5 j} \Delta D I S R A T E_{t-j}+\sum_{j=1}^{k} \theta_{5 j} \Delta R R_{t-j}+ \\
& \sum_{j=1}^{k} \varsigma_{51 j} \Delta T B i l l_{t-j}+\sum_{j=1}^{k} \delta_{5 j} \Delta L M 2_{t-j}+\Omega_{5} u_{5 t-1}+\varepsilon_{5 t}
\end{aligned}
$$$$
\Delta \text { TBill }_{t}=\alpha_{6}+\sum_{J=1}^{K} \beta_{6 j} \Delta I R S_{t-j}+\sum_{j=1}^{k} \lambda_{6 j} \Delta G D P_{t-j}+\sum_{j=1}^{k} \gamma_{6 j} \Delta I N F_{t-j}+\sum_{j=1}^{k} \psi_{6 j} \Delta D I S R A T E_{t-j}+\sum_{j=1}^{k} \theta_{6 j} \Delta R R_{t-j}+
$$$$
\sum_{j=1}^{k} \varsigma_{6 j} \Delta T B i l l_{t-j}+\sum_{j=1}^{k} \delta_{6 j} \Delta L M 2_{t-j}+\Omega_{6} u_{6 t-1}+\varepsilon_{6 t} \ldots
$$

$$
\begin{aligned}
& \Delta L M 2_{t}=\alpha_{7}+\sum_{J=1}^{K} \beta_{7 j} \Delta I R S_{t-j}+\sum_{j=1}^{k} \lambda_{7 j} \Delta G D P_{t-j}+\sum_{j=1}^{k} \gamma_{7 j} \Delta I N F_{t-j}+\sum_{j=1}^{k} \psi_{7 j} \Delta D I S R A T E_{t-j}+\sum_{j=1}^{k} \theta_{7 j} \Delta R R_{t-j}+ \\
& \sum_{j=1}^{k} \varsigma_{7 j} \Delta T B i l l_{t-j}+\sum_{j=1}^{k} \delta_{7 J} \Delta L M 2_{t-j}+\Omega_{7} u_{7 t-1}+\varepsilon_{7 t}
\end{aligned}
$$

Where $\Delta$ is the first difference operator, $u_{1 t-1 \ldots} u_{7 t-1}$ are error correction terms and $\Omega_{1 \ldots . .7}$ are error correction coefficients. These error correction coefficients are expected to capture the adjustments of change in the variables towards long-run equilibrium, while the coefficients, $\beta, \lambda, \gamma, \psi, \theta, \varsigma$ and $\delta$ are expected to capture the short-run dynamics of the model (Muzindutsi \& Sekhampu, 2013). The number of lags (k) is selected based on Akaike Information Criterion (AIC), or Schwarz-Boyesian Information Criterion (SBIC) (Brooks, 2008). Before interpreting VCM results, diagnostic tests such as autocorrelation, hetroscedasticity, normality and parameter stability tests are conducted to check whether the stochastic properties of the model are met (Maddala, 2001).

\section{Empirical Results}

Table 1 show results of correlation analysis. A correlation coefficient is a number between -1 and +1 which shows the magnitude of a relationship between two variables. The higher the absolute value of the coefficient, the stronger the strength of the relationship is. Correlation between IRS and other 5 variables (GDP, INF, DISRATE, RR and M2) is significant at the 5\% level of significance. However, the correlation between IRS and TBill is not statistically significant. This suggests that there is a high level of association between ISR and the other variables except the TBill. 
Table 1: Pairwise Correlations

\begin{tabular}{llllllll}
\hline \multicolumn{1}{l}{} & IRS & GDP & INF & DISRATE & RR & TBill & M2 \\
\hline IRS & 1.000 & & & & & & \\
GDP & $.627^{*}$ & 1.000 & & & & & \\
INF & $.612^{*}$ & $.597^{*}$ & 1.000 & & & & \\
DISRATE & $.819^{*}$ & $-.002^{*}$ & -.462 & 1.000 & & & \\
RR & $.726^{*}$ & -.254 & .296 & $.564^{*}$ & 1.000 & & \\
TBill & .491 & .356 & $.388^{*}$ & .821 & $.369^{*}$ & 1.000 & .000 \\
M2 & $.206^{*}$ & $.621^{*}$ & $.044^{*}$ & $.213^{*}$ & $.021^{*}$ & $.238^{*}$ & 1.000 \\
\hline
\end{tabular}

${ }^{*}$ Correlation is significant at the 0.05 level

Augmented Dickey Fuller unit root test results are shown in Table 2. The coefficients compared with critical values at $1 \%, 5 \%$ and $10 \%$ show that variables were not stationary at their level but they become stationary at first difference. Meaning, statistical evidence concludes that all variables become stationary in their first differences. Therefore, the null hypothesis of non stationary is rejected implying that the variables are integrated of order one at the $1 \%$ level of significance. Thus, the next step is therefore to test for co-integration.

Table 2: Augmented Dickey-Fuller Unity Root Test

\begin{tabular}{lllll}
\hline Variables & $\begin{array}{l}\text { Level } \\
\text { t-Statistic }\end{array}$ & P-values* & $\begin{array}{l}\text { First Difference } \\
\text { t-Statistic }\end{array}$ & P-values* \\
\hline IRS & 5.3110 & 0.0876 & 7.23569 & 0.0000 \\
GDP & 3.5926 & 0.1234 & 5.95621 & 0.0000 \\
INF & 2.6290 & 0.1692 & 3.26140 & 0.0012 \\
DISRATE & 4.2187 & 0.8751 & 6.14258 & 0.0000 \\
RR & 4.9532 & 0.2641 & 4.9532 & 0.0000 \\
TBill & 0.97623 & 0.7234 & 2.31258 & 0.0209 \\
M2 & 2.1245 & 0.3261 & 4.35891 & 0.0000 \\
\hline
\end{tabular}

Table 3: Summary of Johansen Co-Integration Test Statistics

\begin{tabular}{|c|c|c|c|c|c|}
\hline $\begin{array}{l}\text { Ho: No of } \\
\text { equations }\end{array}$ & cointegrating & $\begin{array}{l}\text { Trace Test } \\
\text { Trace } \\
\text { statistics }\end{array}$ & P-values* & $\begin{array}{l}\text { Maximum Eigenvalu } \\
\text { Max-Eigen Statistic }\end{array}$ & P-values* \\
\hline None & & 165.9236 & 0.0213 & 68.0189 & 0.0000 \\
\hline At most 1 & & 96.8910 & 0.0087 & 46.3987 & 0.0000 \\
\hline At most 2 & & 64.5124 & 0.0323 & 32.3458 & 0.0057 \\
\hline At most 3 & & 40.0218 & 0.1692 & 11.0079 & 0.0812 \\
\hline At most 4 & & 25.2134 & 0.8751 & 9.45873 & 0.1249 \\
\hline At most 5 & & 12.6934 & 0.2641 & 7.34578 & 0.3984 \\
\hline At most 6 & & 9.00244 & 0.7234 & 6.62350 & 0.8659 \\
\hline At most 7 & & 6.96373 & 0.3261 & 4.2365 & 0.6804 \\
\hline
\end{tabular}

* MacKinnon-Haug-Michelis (1999) p-values

Using Johansen co-integration test, this paper found two cointegrated equations, as shown by trace statistics and maximum eigenvalue statistics in Table 3. According to the probabilities (P-values) in Table 3 , the null hypothesis that there is no cointegrated vector (None), there is at most 1 and at most 2 are rejected. In other words, all three p-values under trace test and maximum eigenvalue are statistical significant the 0.05 level of significance; meaning that there are two cointegrating equations. Therefore, there is existence of association between explanatory and dependent variables used in this paper. This is in line with most previous findings of a long-run relationship between IRS and its determinants. These two cointegrating equations are also confirmed in the results presented in table 4 where short-run relationship is discussed. 
Table 4: Vector Error Correction Model Results

\begin{tabular}{|c|c|c|c|c|c|c|c|}
\hline $\begin{array}{l}\text { Error } \\
\text { Correction }\end{array}$ & $\Delta$ IRS & $\overline{\Delta G D P}$ & INF & DDISRATE & $\Delta \mathbf{R R}$ & $\Delta$ TBill & $\Delta \mathrm{M} 2$ \\
\hline CointEq1 & $\begin{array}{l}-0.2315^{*} \\
{[-6.1120]}\end{array}$ & $\begin{array}{l}0.0016^{*} \\
{[4.1267]}\end{array}$ & $\begin{array}{l}0.00158 \\
{[1.2354]}\end{array}$ & $\begin{array}{l}0.0056^{*} \\
{[2.641]}\end{array}$ & $\begin{array}{l}-0.170023^{*} \\
{[-4.3126]}\end{array}$ & $\begin{array}{l}0.09632 \\
{[1.4536]}\end{array}$ & $\begin{array}{l}2.3659^{*} \\
{[3.9687]}\end{array}$ \\
\hline CointEq2 & $\begin{array}{l}-0.0607^{*} \\
{[-2.1780]}\end{array}$ & $\begin{array}{l}0.0023 \\
{[1.2359]}\end{array}$ & $\begin{array}{l}0.00191 \\
{[0.2178]}\end{array}$ & $\begin{array}{l}0.9051^{*} \\
4.3244\end{array}$ & $\begin{array}{l}-0.1240^{*} \\
{[-5.1730]}\end{array}$ & $\begin{array}{l}0.0369 \\
{[0.9689]}\end{array}$ & $\begin{array}{l}0.03579 \\
{[0.8567]}\end{array}$ \\
\hline$\Delta \operatorname{IRS}(-1)$ & $\begin{array}{l}0.2361 \\
{[2.9861]}\end{array}$ & $\begin{array}{l}0.0297 \\
{[0.2364]}\end{array}$ & $\begin{array}{l}0.00472 \\
{[1.2497]}\end{array}$ & $\begin{array}{l}0.0252 \\
{[0.0365]}\end{array}$ & $\begin{array}{l}1.1477^{*} \\
{[5.2398]}\end{array}$ & $\begin{array}{l}0.0382 \\
{[1.2031]}\end{array}$ & $\begin{array}{l}0.9075 \\
{[0.2369]}\end{array}$ \\
\hline$\Delta \operatorname{IRS}(-2)$ & $\begin{array}{l}-0.3215 \\
{[-0.0112]}\end{array}$ & $\begin{array}{l}0.0031 \\
{[1.8525]}\end{array}$ & $\begin{array}{l}-0.1245^{*} \\
{[-2.9524]}\end{array}$ & $\begin{array}{l}0.068821 \\
{[0.58874]}\end{array}$ & $\begin{array}{l}0.094572 \\
{[0.0549]}\end{array}$ & $\begin{array}{l}0.077556 \\
{[0.8150]}\end{array}$ & $\begin{array}{l}0.014521 \\
{[1.9713]}\end{array}$ \\
\hline$\Delta \mathrm{GDP}(-1)$ & $\begin{array}{l}0.0414^{*} \\
{[4.0596]}\end{array}$ & $\begin{array}{l}0.2557 \\
{[0.6364]}\end{array}$ & $\begin{array}{l}1.01247^{*} \\
{[3.4831]}\end{array}$ & $\begin{array}{l}0.2291 \\
{[0.0346]}\end{array}$ & $\begin{array}{l}0.7528 \\
{[1.4115]}\end{array}$ & $\begin{array}{l}0.0106 \\
{[0.1225]}\end{array}$ & $\begin{array}{l}0.1227 \\
{[0.4979]}\end{array}$ \\
\hline$\Delta \mathrm{GDP}(-2)$ & $\begin{array}{l}0.0003 \\
{[0.09623]}\end{array}$ & $\begin{array}{l}0.01548 \\
{[0.0008]}\end{array}$ & $\begin{array}{l}0.00428 \\
{[0.9572]}\end{array}$ & $\begin{array}{l}1.0112 \\
{[1.0970]}\end{array}$ & $\begin{array}{l}0.4870 \\
{[0.2365]}\end{array}$ & $\begin{array}{l}0.7191 \\
{[0.0036]}\end{array}$ & $\begin{array}{l}0.6612^{*} \\
{[3.1260]}\end{array}$ \\
\hline$\Delta \mathrm{INF}(-1)$ & $\begin{array}{l}0.003784 \\
{[0.9568]}\end{array}$ & $\begin{array}{l}0.00845 \\
{[0.6897]}\end{array}$ & $\begin{array}{l}0.2317 \\
{[1.4235]}\end{array}$ & $\begin{array}{l}0.07891 \\
{[0.0812]}\end{array}$ & $\begin{array}{l}1.0842 \\
{[0.1985]}\end{array}$ & $\begin{array}{l}0.3561 \\
{[1.3570]}\end{array}$ & $\begin{array}{l}0.04168 \\
{[0.9452]}\end{array}$ \\
\hline$\Delta \mathrm{INF}(-2)$ & $\begin{array}{l}0.00724 \\
{[0.9721]}\end{array}$ & $\begin{array}{l}0.00416 \\
{[1.0145]}\end{array}$ & $\begin{array}{l}0.08435 \\
{[0.8467]}\end{array}$ & $\begin{array}{l}0.08437 \\
{[1.4217]}\end{array}$ & $\begin{array}{l}0.00942 \\
{[0.9218]}\end{array}$ & $\begin{array}{l}0.03721 \\
0.008246]\end{array}$ & $\begin{array}{l}1.0041 \\
{[0.17214]}\end{array}$ \\
\hline$\triangle$ DISRATE $(-1)$ & $\begin{array}{l}0.425663^{*} \\
{[6.0235]}\end{array}$ & $\begin{array}{l}0.002324^{*} \\
{[3.92651]}\end{array}$ & $\begin{array}{l}0.02846 \\
{[0.00457]}\end{array}$ & $\begin{array}{l}0.28564 \\
{[0.00695]}\end{array}$ & $\begin{array}{l}0.030944^{*} \\
{[6.23564]}\end{array}$ & $\begin{array}{l}0.00589 \\
{[0.000568]}\end{array}$ & $\begin{array}{l}0.026951 \\
{[0.004789]}\end{array}$ \\
\hline$\Delta$ DISRATE $(-2)$ & $\begin{array}{l}0.00823 \\
{[0.0845]}\end{array}$ & $\begin{array}{l}0.09856 \\
{[0.0089]}\end{array}$ & $\begin{array}{l}0.00149 \\
{[0.84239]}\end{array}$ & $\begin{array}{l}0.00654 \\
{[0.0124]}\end{array}$ & $\begin{array}{l}0.2014 \\
{[2.0652]}\end{array}$ & $\begin{array}{l}0.05984 \\
{[0.00546]}\end{array}$ & $\begin{array}{l}0.0213 \\
{[0.58971]}\end{array}$ \\
\hline$\Delta \mathrm{RR}(-1)$ & $\begin{array}{l}0.9546^{*} \\
{[4.0578]}\end{array}$ & $\begin{array}{l}0.00569 \\
{[0.004572]}\end{array}$ & $\begin{array}{l}0.00781 \\
{[0.07492]}\end{array}$ & $\begin{array}{l}0.434844 * \\
{[3.2651]}\end{array}$ & $\begin{array}{l}0.000174^{*} \\
{[3.26329]}\end{array}$ & $\begin{array}{l}0.0005 \\
{[0.008476]}\end{array}$ & $\begin{array}{l}0.09687 \\
{[0.94542]}\end{array}$ \\
\hline$\Delta \mathrm{RR}(-2)$ & $\begin{array}{l}0.387631 \\
{[1.4562]}\end{array}$ & $\begin{array}{l}0.014246 \\
{[0.0015]}\end{array}$ & $\begin{array}{l}0.00158 \\
{[0.09421]}\end{array}$ & $\begin{array}{l}0.015836 \\
{[0.00078]}\end{array}$ & $\begin{array}{l}0.059121 \\
{[1.8561]}\end{array}$ & $\begin{array}{l}0.069257 \\
{[0.00659]}\end{array}$ & $\begin{array}{l}0.0096 \\
{[0.00784]}\end{array}$ \\
\hline$\Delta$ TBill(-1) & $\begin{array}{l}0.00014 \\
{[1.0025]}\end{array}$ & $\begin{array}{l}0.8752 \\
{[0.00784]}\end{array}$ & $\begin{array}{l}0.02531 \\
{[0.07195]}\end{array}$ & $\begin{array}{l}0.32654 \\
0.89452]\end{array}$ & $\begin{array}{l}0.04628 \\
{[2.08742]}\end{array}$ & $\begin{array}{l}0.149281^{*} \\
{[3.1268]}\end{array}$ & $\begin{array}{l}0.00145 \\
0.00678]\end{array}$ \\
\hline$\Delta \mathrm{TBill}(2)$ & $\begin{array}{l}0.0012589 \\
{[0.0012847]}\end{array}$ & $\begin{array}{l}0.87659 \\
{[0.05123]}\end{array}$ & $\begin{array}{l}0.007942 \\
{[0.71549]}\end{array}$ & $\begin{array}{l}0.0589470 \\
{[0.005487]}\end{array}$ & $\begin{array}{l}0.05362 \\
{[0.4286]}\end{array}$ & $\begin{array}{l}0.52978 \\
0.06482]\end{array}$ & $\begin{array}{l}0.00954 \\
{[0.03624]}\end{array}$ \\
\hline$\Delta \mathrm{M} 2(-1)$ & $\begin{array}{l}0.84561^{*} \\
{[3.0462]}\end{array}$ & $\begin{array}{l}0.00390 \\
{[0.08215]}\end{array}$ & $\begin{array}{l}0.08410 \\
{[0.8249]}\end{array}$ & $\begin{array}{l}0.701245 \\
{[0.074521]}\end{array}$ & $\begin{array}{l}0.00085^{*} \\
{[5.9062]}\end{array}$ & $\begin{array}{l}0.000914 \\
0.04578]\end{array}$ & $\begin{array}{l}0.1487 \\
{[0.000174]}\end{array}$ \\
\hline$\Delta \mathrm{M} 2(-2)$ & $\begin{array}{l}0.124572 \\
{[1.49741]}\end{array}$ & $\begin{array}{l}0.0045879 \\
{[0.94044]}\end{array}$ & $\begin{array}{l}0.07194 \\
{[0.07267]}\end{array}$ & $\begin{array}{l}0.00145984 \\
{[0.63410]}\end{array}$ & $\begin{array}{l}0.7456891 \\
{[2.97969]}\end{array}$ & $\begin{array}{l}0.005894 \\
{[0.09842]}\end{array}$ & $\begin{array}{l}0.48792 \\
{[1.00454]}\end{array}$ \\
\hline
\end{tabular}

t-statistics in [ ], *significant at the 5\% level, 2 lags were selected based on AIC

In general, the existence of a co-integrating relationship between the IRS and the combination of selected macroeconomic variables suggests that these variables explain the long run equilibrium in the IRS. However, this does not shed any light on short-run dynamics (Niyimbanira, 2013). Therefore, VECM (Equations 10 to 16) is undertaken in order to establish the adjustment towards long-run equilibrium, and the short-run dynamics between the variables. VECM results in Table 4 show that the first cointegrating equation (CointEq1) has five significant coefficients (IRS, GDP, DISRATE, RR, M2). However, only two variables (IRS and RR) have the correct sign (negative). Among these two variables IRS is the most significant coefficient; with a t-value of -6.1120 as compare to -4.3126 for RR. This suggests that IRS constitutes the true co-integrating relationship in the first co-integrating equation. In the second equation, there three coefficients (IRS, DISRATE, RR) that are statistically significant at the 0.05 level of significance; but only two of them (IRS, RR) have the correct sign. The most significant variable in the equation 2 is RR; suggesting that RR constitutes the true co-integrating relationship in the second cointegrating equation. Furthermore, this first equation is better than the second one as the second one has only three significant variables. This suggests that IRS shows strong evidence of error correction to the first co-integrating equation. The interpretation of the two co-integrating equations is that the second equation explains the long run equilibrium in reserve requirements (RR), while the first equation explains the long-run equilibrium in interest rate spreads (IRS). After conducting LM tests, it revealed that there are no autocorrelations, nor hetroscedasticity in the VECM residuals. Thus results of VECM are presented in table 4. 


\section{Conclusion}

The financial system is one of the most important sources of funding for economic decisions related to consumption and investment. Therefore, providing medium term productivity growth as well as a more dynamic and sustainable economic growth rates through financing capital accumulation and technological innovations., Eventually this entails that the price of borrowing from financial institutions and its efficiency which is measured by interest rate spreads are crucial when considering the possibility of allocation additional financial potential in a given economy, which in turn instigate acceleration or sustainability of economic growth (Georgievska et al., 2008). Therefore, narrowing the interest rate spread which is the difference between the interest rate charged to borrowers and the rate paid to depositors would be the resultant benefits of financial liberalization and consequentially the growth of the financial sector (Mettle, 2013). This is on the premise that liberalization augments and improves competition and efficiency in the financial sector. A wide deposit lending interest rate spread could therefore be symptomatic of banking sector inefficiency or an indication on the level of development in the financial sector (Tennant \& Folawewo, 2008).

The aim of this paper was to investigate the determinants of interest rate spreads in South Africa. A cointegration approach and VECM tests were used to assess the relationship between the IRS and a set of macroeconomic variables (GDP per capita, Inflation, discount rate, reserve requirements rate, Treasury Bill and M2). The ADF test reveal that all variables are stationary at first difference and Johansen cointegration test revealed that there is a long-run association between the variables. The cointegrating equation indicated that all variables used in this study have a positive long-run effect on interest rate spread as was expected. Thus, this paper emphasised that there is a long-run relationship between the IRS and a combination of the selected macroeconomic variables except Treasury Bill which was not found statistically significant. In the short run, there was a significant relationship between the IRS and GDP, inflation, discount rate, reserve requirement rate and M2. However, Treasury Bill was not significant in predicting changes in IRS. This was confirmed by variance decomposition analysis which revealed that shocks in the IRS are not explained by shocks from Treasury Bill. In other words, there was no evidence on the effect of Treasury Bill changes on IRS in the short-run. The general conclusion of the study is that there is a long-run relationship between macroeconomic variables and the IRS in South Africa. This confirms previous findings that the effect IRS is observed in the long-run and in short-run. These findings suggest that policymakers especially monetary authorities in South Africa should consider the implications of macroeconomic policies on the Interest rate spreads and how it affect consumers.

\section{References}

Afzal, A. \& Mirza, N. (2010). The determinants of interest rate spread in Pakistan's commercial banking sector. Working Paper No. 01-10. Lahore, Pakistan: Centre for Research in Economics and Business.

Akinlo, A. E. \& Owoyemi, B. O. (2012). Determinants of Interest rate Spread in Nigeria: An Empirical investigation. Modern Economy, 3, 837-845.

Aqeel, A. \& Nishat, M. (2005). The Determinants of Foreign Direct Investment in Pakistan. Paper presented at the 20 Annual PSDE Conference, Islamabad, 10-12 January.

Banda, C. M. (2010). The Determinants of Banking Sector Interest Rate Spreads in Zambia. (Unpublished Masters Thesis). University of Zambia.

Barajas, A., Steiner, R. \& Salazar, N. (1996). Interest spreads in banking Costs: costs, financial taxation, market power and loan quality in the Colombian case, 1974-1988. IMF Working Paper No. 110. Washington, D.C.

Brock, P. \& Rojas-Suarez (2000). Understanding the Behaviour of Bank Spreads in Latin America. Journal of Development Economics, 63(1), 113-134

Brook, C. (2008). Introductory Econometrics for Finance (2nd Ed.). UK: Cambridge University Press.

Caprio, G., Jr. (1996). Banking on financial reform? A case of sensitive dependence on initial conditions. In G. Caprio, Jr., I. Atiyas and W.J. Hanson, eds., Financial Reform: Theory and Experience. New York: Cambridge University Press.

Chan, N. H. (2010). Time Series: Applications to Finance with R and S-Plus. (2nd Ed.). New Jersey: John Wiley \& Sons.

Cho, Y. J. (1988). The Effect of Financial Liberalization on the Efficiency of Credit Allocation: Some Evidences from South Korea. Journal Development Economics, 29, 101-110. 
Demirguc-Kunt, A. \& Huizinga, H. (1999). Determinants of Commercial Bank Interest Margins and Profitability: Some International Evidence. World Bank Economic Review, 13(2), 379-408.

Elkayam, D. (1996). The effect of monetary policy on local-currency segment in Israel 1986-1900. Banking of Israel Economic Review, 68, 1-22.

Engle, R. F. \& Granger, C. W. J. (1987). Co-integration and Error Corrections: Representation, Estimation and Testing. Econometrica, 55(2), 251-276.

Engle, R. F. \& Yoo, B. S. (1987). Forecasting and Testing in Cointegrated Systems. Journal of Econometrics, 35, 143-159.

Fry, M. (1995). Money, Interest, and Banking in Economic Development. (2nd Ed.). Baltimore: Johns Hopkins University Press.

Georgievska, A., Georgievska, L., Stojanovic, A. \& Todorovic, N. (2008). Sovereign rescheduling probabilities in emerging markets: a comparison with credit rating agencies' ratings. Journal of Applied Statistics, 35, 1031-1051.

Hainz, C., Hlavacek, M. \& Horvath, R. (2014). The Interest Rate Spreads in the Czech Republic: Different Loans, Different Determinants? Economic Systems, 38, 43-54.

Hanson, J. \& Rocha, R. (1986). High Interest Rates, Spreads, and the Cost of Intermediation: Two Studies. Industry and Finance Series, 18, World Bank, Washington.

Harris, R. (1995). Using Cointegration Analysis in Econometric Modelling. London: Prentice Hall/Harvester Wheatsheaf.

Ho, T. \& Saunders, A. (1981). The Determinants of Bank Interest Margins: Theory and Empirical Evidence. Journal of Financial and Quantitative Analysis, 16(4), 581-600.

Johansen, S. \& Juselius, K. (1990). Maximum Likelihood Estimation and Inference on Cointegration with Applications to the Demand for Money. Oxford Bulletin of Economics and Statistics, 2(2) 169210.

Johansen, S. (1988). Statistical Analysis of cointergration vector. Journal of Economic Dynamics and control, 12(2-3), 231-254.

Keller, G. \& Warrack, B. (2003). Statistics for Management and Economics. Australia: Thomson Learning. Inc.

Maddala, G. (2001). Introduction to Econometrics (3rd Ed.). West Sussex: John Wiley \& Sons.

Mann, P. S. (2004). Introductory Statistics (4th Ed.). New Jersey: John Wiley \& Sons. Inc.

MacKinnon, J. G., Haug, A. A. \& Michelis, L. (1999). Numerical distribution functions of likelihood ratio tests for cointegration. Journal of Applied Econometrics, 14, 563-577.

Mettle, F. A. (2013). The Determinant of Bank Interest rate spreads in Ghana (Unpublished Masters Thesis). KNUST.

Muzindutsi, P. F. \& Sekhampu, T. J. (2013). Socially Responsible Investment and Macroeconomic Stability in South Africa: An Application of Vector Error Correction Model. The Journal of Applied BusinesS Research, 29(6), 1623-1630.

Niyimbanira, F. (2013). An Econometric Evidence between Inflation and Economic Growth in South Africa. Mediterranean Journal of Social Sciences, 4(13) 219-225.

Paroush, J. (1994). The effect of uncertainty, market structure and collateral policy on the interest rate spread. Bank of Israel Banking Review, 4, 79-94.

Robinson, P. M. \& Marinucci, D. (2003). Semiparametric Frequency Domain Analaysis of Fractional Cointergration, in : P.M. Robinson (ed), Times Series with Long Memory. Oxford University Press, 334-373.

Tennant, D. \& Folawewo, A. (2008). Determinants of Interest Rate Spreads in Sub- Saharan Countries: A Dynamic Panel Analysis. A paper presented at the 13th Annual African Econometrics Society Conference, Pretoria, 9- 11th July.

Zarruk, E. (1989). Bank Spread with Uncertain Deposit Level and Risk Aversion. Journal of Banking and Finance, 13, 797-810. 